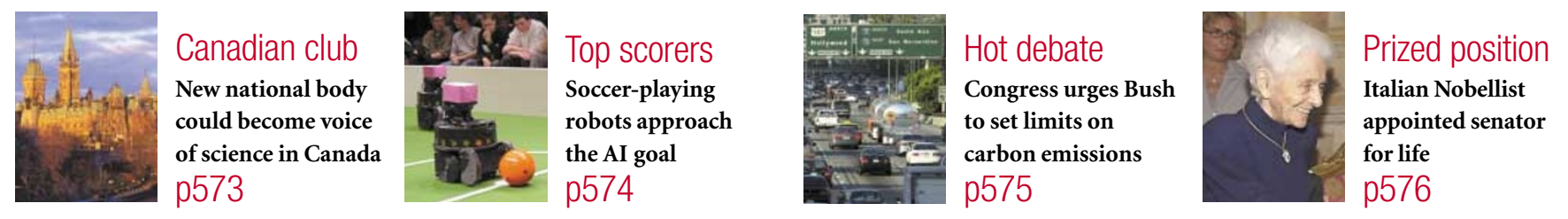

\title{
Mad-cow outbreak spurs German drive to combat prion diseases
}

\section{Alison Abbott, Munich}

German biologists and veterinarians are preparing to launch a coordinated investigation into prion-based diseases, which include bovine spongiform encephalopathy (BSE), or mad cow disease.

At a government-sponsored meeting in Munich on 20 July, researchers met to determine questions that should be asked and the necessary tools for studying these diseases, of which Germany has little direct experience.

Because Germany was thought to be free of BSE, German research on the diseases, known collectively as transmissible spongiform encephalopathies (TSEs), figured little during the 1990s.

But since the first cases were discovered there last year (see Nature 408, 506; 2000), sources of research funding have been springing up. Sponsors include consumerprotection and research agencies at both state and federal level. Earlier this year, for example, three states earmarked special research funds for prion-based diseases. In May the federal government allocated DM27 million (US\$12 million) to such research.

A significant part of the federal funding will support a "research platform" to coordinate the mushrooming research and provide infected material for study.

"So much has been happening so fast that it is hard to follow - and coordinate with -

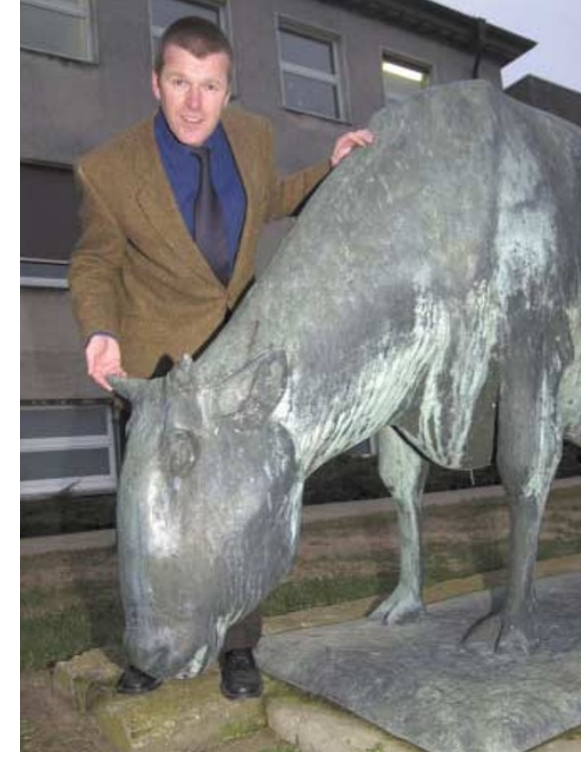

Research model: Martin Groschup wants to harmonize German and French efforts on BSE.

initiatives in other parts of Germany," says Hans Kretzschmar, a neuropathologist at the Ludwig Maximilian University of Munich.

Aside from sponsoring meetings such as last month's, the government will create a web-page repository for results and resources, including material from a federally funded pathogenesis study due to begin at the end of the year. The study will be based at the new Institute for Emerging and Unconventional Infectious Agents on the remote Baltic island of Riems, north of Greifswald, where 50 cattle will be deliberately infected with BSE. As TSE research increases, "German scientists will need a more direct supply of infected tissue", explains Martin Groschup, a veterinary virologist at the Federal Research Centre for Virus Diseases of Animals in Tübingen, who heads the pathogenesis programme.

Regular samples of biological fluids, including blood, cerebrospinal fluid and urine, will be taken from the cattle, and a small number will be slaughtered every few months for complete dissection. The tissues will be distributed to TSE researchers.

Groschup hopes to harmonize the programme with a similar exercise being proposed in France. If the French programme materializes, he says, "we want the innoculum and procedures to be standardized so that results from research on the materials are truly comparable."

Kretzschmar and Groschup are spearheading the TSE research programme in Bavaria, which, with DM20 million of funding over two years, is Germany's largest such state programme. Bavaria is also building a DM38-million TSE research centre in Munich for work on infected animals, particularly mice. Two other states, Baden-

\section{Drugs firms inflate research costs, watchdog says}

\section{Jonathan Knight}

A watchdog group has challenged the US pharmaceutical industry's claim that drugs cost an average of $\$ 500$ million to develop. The actual cost, according to a report from Washington-based Public Citizen, is closer to $\$ 100$ million. The group charges that industry lobbyists have misled Congress and the public to justify high prices.

According to the report, financial risks are lower because companies cherry-pick research from publicly funded laboratories. An internal document obtained by Public
Citizen from the National Institutes of Health estimates that over half the research that led to development of the top five new drugs in 1995 came from the public sector.

But this ignores the gap between lab bench and pharmacy, says Iain Cockburn, an economist at Boston University. The report's authors "are too ready to discount the risk of trying to turn promising lab research into a marketable drug", he says.

Public Citizen claims that the often-cited cost of $\$ 500$ million ignores tax breaks on research and development. Bob Young, who directed the project, says it is also inflated by a theoretical value for the 'opportunity cost' of capital, or what it would have earned if invested elsewhere. But Joseph DiMasi, the economist at Tufts University in Boston on whose 1991 study the higher figure is based, says: "Opportunity cost is a real factor."

Public Citizen has called on Congress to institute price caps for prescription drugs supplied by Medicare, the federal insurance programme for retired people.

http://www.citizen.org/congress/drugs/

r\&dscarecard.htmla 
Württemberg and Niedersachsen, have smaller programmes of their own.

The upsurge in funding has raised eyebrows among health researchers specializing in more common diseases. The human TSE variant CreutzfeldtJakob disease (vCJD) — has so far claimed

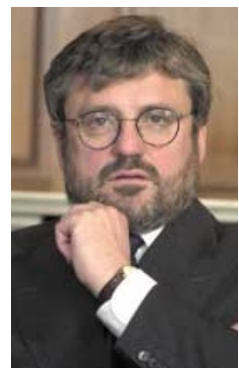

Hans Kretzschmar says prion research is worthwhile. only around 100 victims, none of them in Germany.

"CJD is not a big health hazard, but it is worth funding generously," says Kretzschmar. This is not just because it raises hopes of curing a rare disease, he argues, but also because it feeds into research on neurodegenerative diseases generally, which usually involve amyloid proteins. "The only difference between these diseases and diseases such as Alzheimer's is that TSEs are transmissible," he says.

One of the Bavarian projects involves screening chemical libraries for their ability to prevent prion proteins from aggregating, using a new screen that tracks the diffusion time of a single fluorescently tagged prion molecule. This work will be done by academics because, says Kretzschmar, "the pharmaceutical industry is not interested in finding cures for vCJD because it is so rare".

Another project is to create genetically modified cattle that lack the gene for the prion protein $\mathrm{PrP}$, and which therefore cannot contract BSE.

\section{Medical journals seek means to free authors from industry}

\section{Paul Smaglik, Washington}

Several leading medical journals are planning a new publishing policy designed to empower academic authors who collaborate with industry.

Aimed at authors who work with drug companies on clinical trials, the policy should help academics retain full control of the content and timing of research results produced in industrial collaborations.

Critics contend that drug companies can exert excessive influence over the publication of work that they have paid for, potentially suppressing negative results, for example.

The journals - including the Journal of the American Medical Association (JAMA), the New England Journal of Medicine and The Lancet - will announce the joint policy in mid-September. They are expected to reject reports from trials sponsored by drug companies unless the authors have been granted explicit control over the data and the decision to publish.

In an interview with Nature, Jeffrey Drazen, editor-in-chief of the New England Journal of Medicine, was tight-lipped about the details of the policy, whose existence was reported in the Washington Post on 5 August. But he was less coy about the circumstances that prompted the editors to develop it.

"Academic investigators have had less and less opportunities to work with pharmaceutical sponsors with respect to study design, data analysis and interpretation, and manuscript drafting," he says. "They're given a 'take it or leave it' stance."

The new policy is intended to help academic investigators negotiate more favourable terms with companies, Drazen says. As companies seek the endorsement that publication of a positive trial in a journal implies, they may be willing to give more freedom to their academic collaborator.

George Lundberg, editor-in-chief of online medical journal Medscape, says that the policy's overall goals are "praiseworthy". But he is unsure how effective it will be in helping journals establish more editorial independence. "The devil will be in the details," he says.

For example, Lundberg wonders how far any policy where authors have to pledge their independence can be extended, and whether authors will be expected to vouch for their full independence from their universities and granting agencies as well.

News of the policy attracted a mixed reception. A spokesperson for the Pharmaceutical Research and Manufacturers of America questions whether the policy is necessary. But the New York-based Citizens for Responsible Care \& Research, a consumer group that has been critical of medical research conduct, says that it supports the policy's ends, but doubts that it will contain the means to achieve them.

\section{Golf course threatens to leave hole in fossil records}

\section{Rex Dalton, San Diego}

A planned golf course outside Denver, Colorado, could swallow up a valuable dinosaur track site that includes the world's only known tracks of a species from 65 million years ago, palaeontologists say.

According to the plans, some of the tracks are to be covered with dirt, and some cut out of their stone and removed for display elsewhere. Others would be preserved in situ amid the fairways and greens of the proposed municipal course in the small town of Golden in the Rocky Mountains.

But the plans have met with fierce opposition from geologists and palaeontologists. William Caneer, a retired geologist from the Colorado School of Mines, says: "Palaeontologists spend half their lives digging specimens up; now the city wants to cover tracks with dirt. It makes smoke come out of my ears."

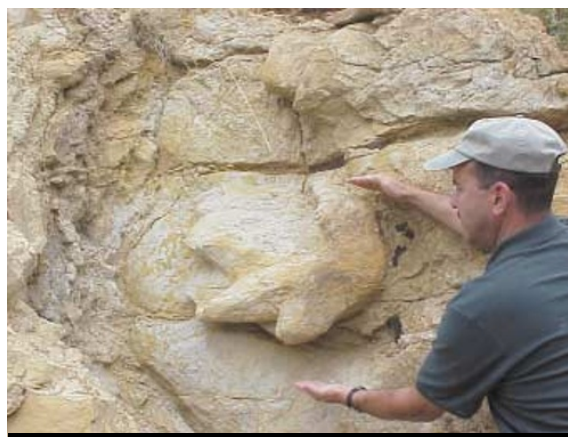

Rough justice? Many of the fossils at Golden could be covered over by fairways and greens.

Colorado's state archaeologist, Susan Collins, has requested a survey of the palaeontology specimens at the site known as the Parfet clay pits, a former clay mine on the eastern edge of the Rocky Mountains.

Collins says her agency will determine what can be done with the track site after the survey is complete. But she has not ruled out accepting the plan for the golf course.

Once a waste dump for coal-plant ash, and broken bottles from the nearby Coors Brewery, the privately owned clay pits recently donated to the city of Golden were for years the domain of amateur rock hunters, who cut out tracks with highpowered rock saws.

Around 1985, Martin Lockley, a geologist at the University of Colorado at Denver, and colleagues found in the pits the first ever identified tracks of a ceratopsian, along with the only known US track of the crocodilelike champsosaur. Golden has contracted Lockley to assist in preserving the tracks during construction of the golf course.

Lockley, who curates the world's largest dinosaur-track collection at his university, says the course could incorporate the history of the site by including appropriate displays of the tracks. 